Relations industrielles

Industrial Relations

\title{
Union Merger Support
} A Tale of Two Theories

\section{Deux théories à l'appui de la fusion syndicale} Soporte para la unificación de los sindicatos, una historia de dos teorías

\section{Kay Devine et Yonatan Reshef}

Volume 53, numéro 3, été 1998

URI : https://id.erudit.org/iderudit/005274ar

DOI : https://doi.org/10.7202/005274ar

Aller au sommaire du numéro

\section{Éditeur(s)}

Département des relations industrielles de l'Université Laval

\section{ISSN}

0034-379X (imprimé)

1703-8138 (numérique)

Découvrir la revue

\section{Citer cet article}

Devine, K. \& Reshef, Y. (1998). Union Merger Support: A Tale of Two Theories. Relations industrielles / Industrial Relations, 53(3), 517-534.

https://doi.org/10.7202/005274ar

Tous droits réservés (C) Département des relations industrielles de l'Université Laval, 1998
Ce document est protégé par la loi sur le droit d'auteur. L'utilisation des services d'Érudit (y compris la reproduction) est assujettie à sa politique d'utilisation que vous pouvez consulter en ligne.

https://apropos.erudit.org/fr/usagers/politique-dutilisation/ 


\title{
Union Merger Support
}

\section{A Tale of Two Theories}

\author{
KAY DEVINE \\ Department of Organizational Analysis, Faculty of Business, University of Alberta, \\ Edmonton, Alberta. \\ YONATAN RESHEF \\ Department of Organizational Analysis, Faculty of Business, University of Alberta, \\ Edmonton, Alberta.
}

This research examines the individual decision making of the Energy and Chemical Workers' Union rank and file members in their choice to support or oppose a three-way merger with the Paperworkers' Union and the Communications and Electrical Workers' Union. Two theories, one economic and one behavioral, are used to explain member voting preferences. Results demonstrate that both instrumental and image considerations need to be taken into account when predicting the outcome of a union merger vote.

Merger activity among unions is intensifying as labour strives to survive and prosper in a turbulent environment. For example, in Canada unions have been exposed to an environment of severe recessions, foreign competition, declining employment in unionized industries and restructuring in the public sector (Chaison 1996). Furthermore, it is doubtful that the environment will change for the better in the near future. As a result, Canadian unions are exploring merger options as a means to enhance growth, power and their own strategic capability (Chaison 1996; Stratton-Devine 1992).

The unions' officers initiate such alliances (Brooks and Gamm 1976), but the realization of most mergers ultimately rests upon a constitutionally required membership vote. Oddly enough, union merger research has virtually ignored the individual member. Little exploration has been conducted into union merger decision-making processes, and decisionmaking theories in the merger literature are nonexistent. 
This research examines the individual decision making of rank and file members in their choice to support a merger, drawing upon two approaches to decision making - a rational-economic (or maximization) model and a behavioral model, image theory. The data for the study were collected from a merger situation whereby members of the Energy and Chemical Workers' Union, the Canadian Paperworkers' Union and the Communications and Electrical Workers of Canada voted to support a three-way merger.

\section{UNION MERGER BACKGROUND}

Past studies on union mergers have focused on a number of topics. The most widely covered area is the motivation to merge (Adams 1984; Brooks and Gamm 1976; Chaison 1986; Chitayat 1979; Conant and Kaserman 1989; Dewey 1971; Dunlop 1990; Freeman and Brittain 1977; Janus 1978; Troy 1986; and Tyler 1986). A review of prior work reveals that membership decline, financial difficulty, overlapping jurisdictions, lack of economies of scale, the need to increase bargaining power, and protection against raiding have been the main forces prompting mergers.

Other research has examined the frequency of mergers (Chaison 1980, 1986; Dewey 1971; Janus 1978), forms of mergers (Chaison 1986; Freeman and Brittain 1977), the merger process (Brooks and Gamm 1976; Chaison 1986), and merger effects and benefits (Brooks and Gamm 1976; Chaison 1986; Janus 1978; Stratton-Devine 1992). Of this research, three studies explored the dynamics of mergers at the level of the individual member. Chaison (1986) examined why members oppose a merger, and concluded from anecdotal data that members do not support mergers which might result in the submersion of their own interests and identity. Cornfield (1991) analyzed factors which affected state employee association members' level of support of merging with a national labor union. He found that members with lower socioeconomic status were more supportive of merging with a larger union due to their desire to lessen social inequality. McClendon, Kriesky, and Eaton (1995) examined determinants of voting behavior in a study of an independent union of employees working for Dow Jones who rejected a proposed affiliation with a national union. They found that opposition was influenced by the perception that the affiliation would lead to more strikes, an increase in dues and the employer's "vote no" campaign.

Chaison's (1986) research implied that psychological considerations such as identity and fit were critical to members' decisions. As such, economic justifications did not play a dominant role. In contrast, McClendon et al. (1995), and Cornfield's (1991) results suggested that members' deci- 
sions were motivated by economic factors, e.g., avoiding strikes, keeping dues low, and raising wages. Each explanation is valid within the context and boundaries of its own design, yet each is limited by the lack of, or use of only one theoretical perspective. This study extends the literature by examining simultaneously both psychological and economic explanations in a merger vote of three national unions. We propose that both fit (psychological) and maximization (economic) considerations are salient to union members when voting for or against a merger. To demonstrate this, two theories - rational decision theory and image theory - are utilized in an examination of union member voting preferences in a merger decision. This study improves upon past research by: (1) examining a merger situation of three national unions; (2) using quantitative and qualitative data; (3) surveying rank and file members employed by numerous organizations across Canada; and (4) integrating theory from two disciplines to explain the merger vote decision making.

\section{DECISION-MAKING THEORIES}

\section{The Rational-Economic Model}

Over the years, scientific interest in how individuals make decisions has blossomed, with the result that different perspectives have emerged. One of the most widely accepted notions is the classical rational-economic model of decision making. Rational decision theory is a normative, prescriptive concept that presumes that decision makers are fully autonomous people, well knowing what they want (Vlek 1987). It suggests that individuals conduct thorough evaluations of the potential outcomes of available options, and select that action for which the consequences have the greatest expected utility, or maximization (Mitchell, Rediker and Beach 1986).

Applying this theory to union members' decisions to support a merger would suggest that maximization of utility is the principal motive for voting to merge. In other words, the instrumentality, or the perception that the merger would improve conditions, should influence the decision-making process. In essence, this proposition corresponds to research that has developed around the initial decision to unionize. For example, support for unions increases with: (1) job dissatisfaction; (2) a perception that a union will improve employment conditions (instrumentality); (3) the degree of social support for bargaining; and (4) the extent to which employees have limited alternative employment opportunities. "Studies of this type [multivariate models of employee support for unions] take worker cognitive structures as given and assume rational decision-making processes to predict voting behavior and related outcomes" (Lawler 1990: 199). 
In the current study, union members must determine whether or not to vote in favour of a merger. Given rational-economic theory, members should vote in favor of a merger if they beleive that it will improve conditions (instrumentality).

Rational-economic theory is not without its critics. The limited applicability of rational decision methods has been recognized (Simon 1957), and the concept of procedural rationality has been questioned (e.g., Braybrooke and Lindblom 1963; Collingridge 1982). Further, "at the level of individual decisions and of decision makers' self report about how and why they make the decision they did, traditional decision theory proves to be descriptively insufficient. Research at this level has led many researchers to the conclusion that traditional theory simply does not do a very good job of describing what people actually do" (Beach and Mitchell 1990: 3). As a result, a number of alternative behavioral decision theories have been proposed (Vlek 1987), one of which is image theory.

\section{A Behavioral Model: Image Theory}

Image theory is a "descriptive theory of how decisions, usually personal decisions of more than routine importance are made by individual, unaided decision makers" (Beach and Mitchell 1987: 201). According to Beach and Mitchell (1987), image theory is a schema theory. An image is a schema that represents the decision maker's views, or guiding principles relevant to whatever decision is required.

The elements of image theory include: (1) the value image, or the personal beliefs, values and morals that guide how people should behave and how events should transpire, i.e., principles; (2) the trajectory image, or the blueprint of what the decision maker wants his or her future to be, i.e., goals; and (3) the action image, or the "slate of plans" that are being implemented to achieve one's goals, i.e., plans (Beach 1993: 216). "Decision making is the short-hand term for the efforts involved in the management and coordination of these images" (Beach and Mitchell 1990:2).

Decision making consists of two steps: (1) screening, or evaluating whether options are compatible with the decision maker's standards, and (2) choice, or selecting a single option from among a number of alternative choices (Potter and Beach 1994b). Screening decisions are made by assessing candidates in terms of their compatibility or fit with the images, and serve to eliminate options (Beach 1993; Beach and Mitchell 1990; Potter and Beach 1994b). If only one option is being considered and it survives screening, it is the choice by default. In such cases, the decision making criterion is rarely whether or not the choice will result in maximal return. Instead, it concerns whether or not the choice is compatible with (fits with) 
the decision maker's three images without reaching a rejection threshold, a point where the lack of fit becomes so large that a decision maker rejects the option (Beach 1993).

Image theory has not been tested extensively because it is relatively new, having been introduced only in 1986. The empirical research that has been conducted primarily examines the screening step, or compatibility test (see Beach et al. 1988; Beach and Strom 1989; Dunegan 1995; and van Zee, Paluchowski and Beach 1992), and the role of violations in screening decisions (Potter and Beach 1994a, 1994b; Rediker et al. 1993). An additional study by Brown, Mitchell and Beach (reported in Mitchell and Beach 1990) examined the value image (principles) and its influence on decisions involving plan adoption, while Rediker examined elements of the trajectory image, or goals (reported in Mitchell and Beach 1990). The majority of these studies, which all yielded supportive results for image theory, employed a controlled experimental design, using scenarios, simulations and role playing. In contrast, the present research tests the theory in a field situation, which adds realistic and heuristic qualities to the study (Kerlinger 1986).

In the current study, a screening decision must be made whereby members must evaluate only one option, i.e., merge with Unions $\mathrm{X}$ and $\mathrm{Y}$ vs. remain with the status quo. In making the decision, the members must determine whether the strategy of merging is compatible with their standards. The first step is a screening decision, using a compatibility test (Beach 1993; Beach 1988). The compatibility test, in this case, involves assessing the proposed options (unions), for their compatibility with the union member's value image (principles), trajectory image (goals) and strategies (plans). If the option passes the compatibility test, the members will support the merger. If not, the members will oppose it.

An example of incompatible partners in a merger situation, which illustrates the significance of "fit," is that of the proposed International Typographical Union (ITU) merger with the International Brotherhood of Teamsters (IBT) in the mid-1980s. Rational decision-making theory would predict that the ITU members, who belonged to a rapidly declining union, would support the merger. That is, a cost-benefit analysis would find that the ITU would have gained in terms of more union power, finances, economies of scale, and, most important, union survival. Weighing these benefits against the perceived costs of such an alliance (i.e., being associated with a union known for corruption and autocracy), it would seem that the former would outweigh the latter, especially since union survival was at stake.

However, ITU members did not approve the merger. Conversations with various members of the ITU, a union that is well known for its strong internal democracy (see Lipset, Trow, and Coleman 1956), revealed that 
they refused to be associated with what they considered to be a corrupt, undemocratic union, despite the potential gains they might have realized through an association with the Teamsters (Stratton 1989). They were proud of their union's democratic tradition, and that heritage was an integral part of their own value image. As such, IBT was an incompatible partner, and did not survive screening.

The IBT-ITU situation served as the genesis for the present study - to determine whether image is a key factor in other merger decisions, and to test empirically the applicability of rational decision theory and image theory in a union merger context.

\section{BACKGROUND}

The merger studied here is a three-way alliance between the 30,000 members of the Energy and Chemical Workers' Union (ECWU), the Canadian Paperworkers' Union (CPU), with 70,000 members, and the Communications and Electrical Workers of Canada (CWC), with 40,000 members. The target of the present study is the Energy and Chemical Workers' Union.

The ECWU represents workers in the oil, chemical, atomic, gas utility, mining, coke, pharmaceutical and allied industries in Canada (ECWU 1981). According to their president, they are "a fortunate union," because their members make between $\$ 25$ and $\$ 40$ an hour, and have a university education, and/or 10-12 years of technical training. Additionally, ECWU members "have a requirement for dialogue and debate on the work site because of the type of industry... Very few others have that." He went on to characterize the members by stating that "they talk about the economy, they talk about Oil Week, they talk about the projections of the industry, they talk about government, and it's a higher level." In short, the typical ECWU member values education and technical expertise (Basken 1992).

Merging is not new for the ECWU; the union came into being as the result of a 1980 merger between the Canadian district of the Oil, Chemical and Atomic Workers' International Union, the Canadian Chemical Workers' Union, and an independent Quebec union of textile workers (Roberts 1990). Later, the 30,000 members of the newly formed ECWU were joined (in 1982) by the National Union of Independent Gas Workers. The rationale behind both mergers was that a unified structure would make it possible to deal more effectively with the powerful corporations that dominate the chemical and energy industries (Roberts 1990). Additionally, the officers of the ECWU espoused the philosophy that affiliation with other unions created a stronger and more effective organization, while expanding existing technical and educational capabilities. 
In September 1992, the merger to be studied here was proposed, again with the goal of creating a stronger, more effective organization. A Merger Agreement was signed by the Executive Boards of the CPU, the CWC, and the ECWU. On November 25 and 26, 1992, in Montreal, Quebec, a special merger convention of the ECWU was held, attended by 332 delegates selected by the rank and file membership as their representatives. At that time, they voted on whether to adopt all of the terms and conditions contained in the Merger Agreement, and whether they agreed to the three-way merger of CPU, CWC, and ECWU. The ECWU delegates represented 30,377 members in good standing, of whom 29,129 (95.89\%) voted in favour of the merger (Basken 1993). Of the other unions, $90.5 \%$ of the CWC members and $83 \%$ of CPU members were in favour. Thus, the new Communications, Energy and Paperworkers' Union of Canada was formed.

\section{METHODS AND SAMPLE}

Prior to the merger vote, a survey instrument designed to measure member perceptions of instrumental merger outcomes (rational decision theory), compatibility with the proposed merger partners (image theory), and the degree of respondents' support of merging was administered to the rank and file delegates who would be taking part in the deciding vote.

The sample consisted of the $332 \mathrm{ECWU}$ delegates who voted on the merger. This group was chosen because they were knowledgeable about the merger, and, more important, they were the actual voters. In August 1992, during the ECWU biennial convention (prior to the merger vote), a cover letter, the research questionnaire (available in both English and French), and a return, prepaid envelope, were given to the delegates in their packet of convention materials. At that point, the delegates were aware of the ongoing merger negotiations, and so had knowledge of the proposed alliance. Delegates were asked to complete the survey, and return it in the prepaid envelopes. Responses were received from 126 individuals, for a response rate of $37.9 \%$.

\section{MEASURES}

\section{Dependent Variables}

Two dependent variables reflected the degree of support for the merger: one for merging with the Paperworkers, and the other for merging with the Communications Workers. Both variables were measured on a scale ranging from 1 (strongly oppose) to 5 (strongly support) in response to the question, "Please indicate how strongly you support merging with the 
Paperworkers (Communications Workers)." While the final merger resolution called for only one vote, which included merging with both CPU and CWC, separating the two unions was necessary in order to test compatibility. CPU and CWC are two distinct organizations, and it was possible that ECWU members would possess differing perceptions of each due to their different reputations.

\section{Merger Instrumentality Variables}

Three composite scales, Growth, Power, and Strategic Capability (Stratton-Devine 1992) were used to measure the effects of instrumentality. All items included in the scales were measured on a 1 (Strongly Disagree) to 5 (Strongly Agree) scale. Growth (Cronbach's alpha $=.60$ ) encompassed three items pertaining to gaining more members and resources, as well as gaining access to a new jurisdiction for organizing. Power (Cronbach's alpha $=.70$ ) was comprised of five items measuring strike, bargaining, political, lobbying, and financial power. Strategic Capability (Cronbach's alpha $=.72$ ), a three-item scale, referred to issues of improving the management of the union, exchanging skills, and exchanging services. Additionally, the items used in the above scales were aggregated to form one single composite variable, called Overall Instrumentality (Cronbach's alpha $=.80$ ).

\section{Image Variables}

Two aggregate scales measured respondents' perceptions of the degree to which each of the two unions was compatible with the decision maker's own value image: Communications Workers' Image (Cronbach's alpha $=.87$ ), and Paperworkers' Image (Cronbach's alpha $=.91$ ). The items used to create each scale measured the decision maker's perceptions of each union relative to his or her specific values in terms of career aspirations, friendship, hobbies/personal interests, morals and ethics. A factor analysis (varimax rotation) performed on the image items to confirm the distinctiveness of the Communications Workers and Paperworkers items indicated that all of the statements designed to measure Paperworker's image loaded together on one factor (eigenvalue $=6.74$ ), which explained $37.4 \%$ of the variance. The Communications Worker's image formed a second factor (eigenvalue $=2.96$ ), which explained $16.4 \%$ of the variance. Because of the factor analysis results and the fact that the correlation of the two scales was low (.41), it was reasonable to conclude that the scales differentiated between the two unions. ${ }^{1}$

1. Independent variable measures and factor analysis results are available from the authors. 


\section{Control Variables}

Control variables were: Age, Gender, Tenure, and Vote. Age and Tenure were included as it is likely that the older the member, the longer he/ she had been associated with the union. A long association might translate into a desire to retain the status quo, as individuals often resist change due to fear of the unknown, poor timing, or no felt need to change (Northcraft and Neale 1990). Gender was included because one of the proposed merger partners (Communications Workers) had a different ratio of male to female members (i.e., more females) than either the Paperworkers or the Energy and Chemical Workers, and this could possibly affect a voting decision. Finally, Vote was a dichotomous variable indicating whether or not the respondent had voted on the 1980 merger which resulted in the creation of the ECWU. This was included as it could influence the degree of support of an individual who had been part of the previous, successful merger effort.

\section{RESULTS}

Table 1 presents the means, standard deviations, and intercorrelations for all variables in the analysis.

\section{Estimation Procedures}

The first two structural equations in Table 2 are the result of regressing the degree of support for merging with the Communications Workers (Equation 1) and with the Paperworkers (Equation 2) on the individual independent and control variables. Equations 3 and 4 in Table 2 are the result of including Overall Instrumentality (the aggregate measure) rather than the individual instrumentality variables.

Results for the first two equations (Table 2) show that only for the Paperworkers are any of the individual instrumentality variables significant. Power $(\mathrm{p}<.01)$ and Strategic Capability $(\mathrm{p}<.05)$ are both statistically significant in terms of the degree of support for merging with CPU. For both the Paperworkers and the Communications Workers, however, the coefficient of the image of the proposed partners is highly significant $(\mathrm{p}<.001)$. None of the controls yields any statistically significant estimate.

Equations 3 and 4 in Table 2 summarize the relative importance of overall Instrumentality and Image of the proposed partner for the degree of support for the merger with each union. For the Communications Workers, the Image coefficient is somewhat larger than that for the overall Instrumentality measure ( .59 vs .54). For the Paperworkers, however, the 
TABLE 1

Means, Standard Deviations and Correlations ( $\mathrm{N}=126)$

\begin{tabular}{|c|c|c|c|c|c|c|c|c|c|c|c|c|c|}
\hline Variables & Means & s.d. & 1 & 2 & 3 & 4 & 5 & 6 & 7 & 8 & 9 & 10 & 11 \\
\hline \multicolumn{14}{|l|}{ Dependent Measures } \\
\hline 1. Support for CPU & 3.635 & 1.177 & & & & & & & & & & & \\
\hline 2. Support for CWC & 4.151 & .849 & .51 & & & & & & & & & & \\
\hline \multicolumn{14}{|l|}{ Instrumentality Measures } \\
\hline 3. Growth & 4.107 & .781 & .50 & .49 & & & & & & & & & \\
\hline 4. Power & 4.288 & .656 & .50 & .37 & .52 & & & & & & & & \\
\hline 5. Strategic Capability & 3.876 & .631 & .58 & .41 & .57 & .40 & & & & & & & \\
\hline 6. Overall Instrumentality & 4.088 & .551 & .65 & .52 & .83 & .80 & .81 & & & & & & \\
\hline \multicolumn{14}{|l|}{ Image Measures } \\
\hline 7. Paperworkers' Image & 3.478 & .825 & .72 & .30 & .47 & .40 & .49 & .55 & & & & & \\
\hline $\begin{array}{l}\text { 8. Communications Workers' } \\
\text { Image }\end{array}$ & 3.882 & .645 & .20 & .56 & .38 & .21 & .25 & .33 & .41 & & & & \\
\hline \multicolumn{14}{|l|}{ Controls } \\
\hline 9. Age & 42.050 & 7.331 & .18 & .10 & .09 & -.04 & .24 & .12 & .19 & .15 & & & \\
\hline 10. Gender & .087 & .283 & .10 & .08 & .16 & .02 & .09 & .10 & .04 & .19 & -.02 & & \\
\hline 11. Tenure & 15.619 & 7.459 & .21 & .12 & .16 & .04 & .10 & .12 & .15 & .10 & .47 & -.02 & \\
\hline 12. Vote in 1980 & .366 & .484 & .05 & .17 & -.01 & -.02 & .05 & .01 & .09 & .10 & .21 & -.06 & .36 \\
\hline
\end{tabular}


TABLE 2

Results of Regression Analysis (N = 126)

\begin{tabular}{|c|c|c|c|c|c|c|c|c|}
\hline \multirow[b]{2}{*}{ Variables } & \multicolumn{2}{|c|}{$\begin{array}{c}\text { Communications Workers } \\
\text { (CWC) } \\
\text { Equation } 1\end{array}$} & \multicolumn{2}{|c|}{$\begin{array}{c}\text { Paperworkers (CPU) } \\
\text { Equation } 2\end{array}$} & \multicolumn{2}{|c|}{$\begin{array}{c}\text { Communications Workers } \\
\text { (CWC) } \\
\text { Equation } 3\end{array}$} & \multicolumn{2}{|c|}{$\begin{array}{c}\text { Paperworkers (CPU) } \\
\text { Equation } 4\end{array}$} \\
\hline & $\beta$ & $t$ & B & $t$ & $\beta$ & $t$ & $\beta$ & $t$ \\
\hline \multicolumn{9}{|l|}{ Instrumentality } \\
\hline Instrumentality (aggregate) & & & & & .54 & $4.63 * * *$ & .73 & $4.85^{* * *}$ \\
\hline Growth & .20 & 1.83 & .00 & .03 & & & & \\
\hline Power & .15 & 1.37 & .38 & $2.99 * *$ & & & & \\
\hline Strategic Capability & .18 & 1.39 & .38 & $2.55^{*}$ & & & & \\
\hline \multicolumn{9}{|l|}{ Image of Proposed Partner } \\
\hline Image of CWC & .58 & $5.60 * * *$ & & & .59 & $5.91 * * *$ & & \\
\hline Image of CPU & & & .75 & $7.30 * * *$ & & & .74 & $7.31 * * *$ \\
\hline \multicolumn{9}{|l|}{ Controls } \\
\hline Age & -.00 & -.20 & -.00 & -.38 & -.00 & -.28 & -.00 & -.17 \\
\hline Gender & -.16 & -.65 & .01 & .04 & -.15 & -.61 & -.04 & -.16 \\
\hline Tenure & .00 & .19 & .02 & 1.90 & .00 & .33 & .01 & 1.63 \\
\hline Vote in 1980 Merger & .24 & 1.70 & -.11 & -.71 & .23 & 1.71 & -.09 & -.61 \\
\hline Adj. $\mathrm{R}^{2}$ & .42 & & .61 & & .43 & & .61 & \\
\hline $\mathrm{F}$ & 11.67 & & 23.84 & & 15.71 & & 31.28 & \\
\hline
\end{tabular}

* $p<.05$

** $\mathrm{p}<.01$

$* * * \mathrm{p}<.00$ 
Image coefficient is approximately the same as the overall Instrumentality measure ( $.74 \mathrm{vs} \mathrm{.73).} \mathrm{These} \mathrm{coefficients} \mathrm{indicate} \mathrm{that} \mathrm{Image} \mathrm{and} \mathrm{Instru-}$ mentality of a proposed partner are equally important in terms of the strength of an individual union member's support.

Next, to assess the relative contribution of Instrumentality and Image to merger support, we conducted a hierarchical regression analysis, a procedure which allows us to compare the explanatory power of each construct. These results are presented in Table 3.

TABLE 3

Results of Hierarchical Regression Analysis ( $\mathrm{N}=126)$

\begin{tabular}{lccc}
\hline \multicolumn{1}{c}{ Variables } & Adj. $R^{2}$ & $\Delta R^{2}$ & $\Delta F^{*}$ \\
\hline Influence of Instrumentality & & & \\
& & & \\
Control Variables & .05 & & \\
Image of Proposed Partner - CPU & .53 & .47 & 116.73 \\
Instrumentality & .60 & .07 & 19.16 \\
& & & \\
Control Variables & .02 & & 52.33 \\
Image of Proposed Partner - CWC & .33 & .30 & 16.84 \\
Instrumentality & .41 & .09 & \\
& & & \\
Influence of Image & & & \\
& .05 & & \\
Control Variables & .39 & .33 & 63.05 \\
Instrumentality & .60 & .20 & 58.99 \\
Image of Proposed Partner - CPU & & & \\
Control Variables & .02 & & \\
Instrumentality & .19 & .17 & 25.15 \\
Image of Proposed Partner - CWC & .41 & .21 & 42.17 \\
\hline
\end{tabular}

* All values of $\Delta \mathrm{F}$ are significant at $\mathrm{p}<.001$

Table 3 indicates that each set of measures adds significantly to the model both before and after controlling for the other set of measures and control variables. For CPU, adding the image of the proposed partner to the control variables increases the $\mathrm{R}^{2}$ from .05 to .53 (change in $\mathrm{R}^{2}=.48$; change in $F=116.73 ; p<.001$ ), while for the $C W C$, it increases $R^{2}$ from .05 to .33 (change in $\mathrm{R}^{2}=.28$; change in $\mathrm{F}=63.05 ; \mathrm{p}<.001$ ). Adding the instrumentality measure increases the value of $\mathrm{R}^{2}$ of each by .07 (change in $\mathrm{F}=$ 19.16; $\mathrm{p}<.001$ ) and .09 (change in $\mathrm{F}=16.84 ; \mathrm{p}<.001$ ), respectively. 
Adding instrumentality to the control variables first, the $\mathrm{R}^{2}$ increases by .33 for CPU (change in $\mathrm{F}=63.05 ; \mathrm{p}<.001$ ), and by .17 for CWC (change in $\mathrm{F}=25.15 ; \mathrm{p}<.001$ ). Adding the image of the proposed partner subsequently increases each $\mathrm{R}^{2}$ by .20 (change in $\mathrm{F}=58.99 ; \mathrm{p}<.001$ ) and .21 (change in $\mathrm{F}=42.17$; $\mathrm{p}<.001$ ), respectively.

\section{DISCUSSION}

The research results indicate that perceptions of both image and instrumentality are critical in terms of member support of a merger. The gains in power and strategic capability were significant in influencing support for merging with the Paperworkers. This is logical, as CPU was the largest of the three unions involved, and was therefore the more likely partner to provide these outcomes to the ECWU. Additionally, the Paperworkers were compatible with the images of the ECWU members. Consequently, they were not rejected as a result of the compatibility test.

Interestingly, the ECWU members perceived no significant instrumental gains by merging with the Communications Workers in terms of the individual measures of growth, power or strategic capability, although the aggregate scale of the three variables is significant. This suggests that instrumentality is significant when all of the elements used to operationalize instrumentality are combined, but that each one, on its own, is insignificant. The mean responses of support of the merger, however, indicated that they were more supportive of merging with CWC than with CPU (4.2 vs 3.6; $t=5.6, \mathrm{p}<.001)$, despite the fact that they believed more instrumental gains would be realized with the CPU merger. This can be explained by examining the means of the image items. The ECWU members rated the Communications members higher in terms of compatibility (3.9 for CWC vs. 3.5 for CPU; $t=5.6, \mathrm{p}<.001$ ). Most likely, this is because the ECWU members perceived CWC to be a better fit in terms of educational level, technological sophistication and expertise. For example, one open-ended question in the questionnaire asked respondents to state what they saw as the main disadvantages of the merger. One respondent stated, "Including CPU. [They are] not similar in high tech, [and are not an] empowered organization." A few others indicated concerns about $\mathrm{CPU}$, similar in nature to this comment.

Theoretically, the study indicates that both the image of the proposed merger partner and instrumentality should be used to examine individual voting behavior. One possibility entail by the study design is that image, or fit, influenced the screening process which, in turn, influenced the final choice. The direction of causality in the decision making poses an interesting question for further research. Another conclusion is that it seems 
that the existence of instrumentality without image, as per the ITU-IBT scenario, is insufficient to generate adequate membership approval.

This research also presents more information relevant to image theory. The CWC passed the compatibility test with higher marks than did the $\mathrm{CPU}$, and received more support as a merger partner. The CPU, however, was also judged to be a good fit, although less so than the CWC. Consequently, neither union was rejected as a potential partner, as borne out by the actual merger vote. Had one of the unions been considered unacceptable, it is likely that the merger vote would have failed, or would not have been supported by nearly $96 \%$ of the representatives.

In practical terms, structural changes such as mergers are occurring more frequently among unions. The main rationale presented to support such changes revolves around a utilitarian notion that larger unions are better able to serve their members. The union officers are the architects of a merger, and provide the primary impetus for the joining of two or more unions. Once an agreement is drawn up, however, it is the members who must decide whether or not to ratify it. Since most decisions of this nature are made intuitively, without recourse to counting and analysis (Mitchell and Beach 1990), it is critical that the officers select a suitable partner (i.e., one that is compatible, or a "good fit") if it is to survive the screening process. Finally, while this article reports results from only one case study, the findings should be generalizable to most North American union merger processes.

\section{REFERENCES}

ADAMS, L. T. 1984. "Labor Organization Mergers 1979-84: Adapting to Change." Monthly Labor Review, Vol. 107, 21-27.

BASKEN, R. 1992. Interview in Edmonton, Alberta, Canada.

BASKEN, R. 1993. Letter to Alberta Labour Relations Board.

BEACH, L. R. 1990. Image Theory: Decision Making in Personal and Organizational Contexts. Chichester, England: Wiley.

BEACH, L. R. 1993. "Broadening the Definition of Decision Making: The Role of Prechoice Screening of Options." Psychological Science, Vol. 4, 215-220.

BEACH, L. R. and T. R. MitChELL. 1987. "Image Theory: Principles, Goals and Plans in Decision Making." Acta Psychologica, Vol. 66, 201-220.

BEACH, L. R. and T. R. MiTCHELL. 1990. "Image Theory: A Behavioral Theory of Decision Making in Organizations." Research in Organizational Behavior. B. M. Staw and L. L. Cummings, eds. Greenwich, Conn.: JAI Press. 
BEACH, L. R., B. SMITH, J. Lundell and T. R. Mitchell. 1988. "Image Theory: Descriptive Sufficiency of a Simple Rule for the Compatibility Test." Journal of Behavioral Decision Making, Vol. 1, 17-28.

BEACH, L. R. and E. STROM. 1989. "A Toadstool among the Mushrooms: Screening Decisions in Image Theory's Comparability Test." Acta Psychologica, Vol. 72, 1-12.

BRAYBROOKE, D. and C. E. LindBlom. 1963. A Strategy of Decision: Policy Evaluation As a Social Process. New York: The Free Press.

BROOKS, G. W. and S. GAMm. 1976. The Causes and Effects of Union Mergers, with Special Reference to Selected Cases in the 60's and 70's. Washington, D.C.: U.S. Department of Labor.

Chaison, G. N. 1980. "A Note on Union Merger Trends, 1900-1978." Industrial and Labor Relations Review, Vol. 34, 114-120.

ChaISON, G. N. 1986. When Unions Merge. Lexington, Mass.: D.C. Heath and Company.

ChAISON, G. N. 1996. Union Mergers in Hard Times. Ithaca, N.Y.: Cornell University Press.

ChITAYAT, G. 1979. Trade Union Mergers and Labor Conglomerates. New York: Praeger.

COLLINGRIDGE, D. 1982. Critical Decision Making: A New Theory of Social Choice. London: Frances Printer.

CONANT, J. L. and D. L. KASERMAN. 1989. "Union Merger Incentives and Pecuniary Externalities." Journal of Labor Research, Vol. X, 243-254.

CORNFIELD, D. B. 1991. "The Attitude of Employee Association Members Toward Union Mergers: The Effect of Socioeconomic Status." Industrial and Labor Relations Review, Vol. 44, 334-348.

DEWEY, L. 1971. "Union Merger Pace Quickens." Monthly Labor Review, Vol. 94, 63-70.

DunEGAN, K. J. 1995. "Image Theory: Testing the Role of Image Compatibility in Progress Decisions." Organizational Behavior and Human Decision Processes, Vol. 62, 79-86.

DunLOP, J. T. 1990. The Management of Labor Unions. Lexington, Mass.: D.C. Heath and Company.

ENERGY AND CHEMICAL WORKERS UNION (ECWU). 1981. "82 Years of Union History." ECWU Journal, 16.

FREEMAN, J. and J. BRITTAIN. 1977. "Union Merger Process and Industrial Environment." Industrial Relations, Vol. 16, 173-185.

JANUS, C. J. 1978. "Union Mergers in the 1970s: A Look at the Reasons and Results." Monthly Labor Review, Vol. 101,13-23.

KERLINGER, F. N. 1986. Foundations of Behavioral Research. 3rd ed. New York: Holt, Rinehart and Winston.

LAWLER, J. J. 1990. Unionization and Deunionization. Columbia, S.C.: University of South Carolina Press. 
LIPSET, S. M., M. TROW and J. Coleman. 1956. Union Democracy. New York: The Free Press.

MCCLENDON, J. A., J. KRIESKY and A. EATON. 1995. "Member Support for Union Mergers: An Analysis of an Affiliation Referendum." Journal of Labor Research, Vol. XVI, 9-24.

MitCHELL, T. R., K. J. REDIKER and L. R. BEACH. 1986. "Image Theory and Organizational Decision Making." The Thinking Organization. H. P. Sims, Jr., D. A. Gioia and Associates, eds. San Francisco: Jossey-Bass Publishers, 293-316.

MitCHELL, T. R. and L. R. BEACH. 1990. “...'Do I Love Thee? Let Me Count...' Toward an Understanding of Intuitive and Automatic Decision Making." Organizational Behavior and Human Decision Processes, Vol. 47, 1-20.

NORTHCRAFT, G. and M. NEALE. 1990. Organizational Behavior. Fort Worth: Dryden Press.

PotTER, R. E. and L. R. BEACH. 1994a. "Decision Making when the Acceptable Options become Unavailable." Organizational Behavior and Human Decision Processes, Vol. 57, 468-483.

POTTER, R. E. and L. R. BEACH. 1994b. "Imperfect Information in PreChoice Screening of Options." Organizational Behavior and Human Decision Processes, Vol. 59, 313-329.

REDIKER, K. J., T. R. MITCHELL, L. R. BEACH and D. W. BEARD. 1993. "The Effects of Strong Belief Structures on Information Processing Evaluations and Choice." Journal of Behavioral Decision Making, Vol. 6, 113-132.

ROBERTS, W. 1990. Cracking the Canadian Formula: The Making of the Energy and Chemical Workers Union. Toronto, Ont.: Between the Lines.

SimON, H. A. 1957. Models of Man: Social and Rational. New York: Wiley.

STRATTON, K. 1989. "Union Democracy in the International Typographical Union: Thirty Years Later." Journal of Labor Research, Vol. X, 119-134.

StratTon-Devine, K. 1992. "Union Merger Benefits: An Empirical Analysis." Journal of Labor Research, Vol. XIII, 133-143.

TROY, L. 1986. "The Rise and Fall of American Trade Unions: The American Labor Movement from FDR to RR." Unions in Transition. S. M. Lipset, ed. San Francisco: ICS Press.

TYLER, G. 1986. "Labor at the Crossroads." Unions in Transition. S. M. Lipset, ed. San Francisco: ICS Press.

VAN ZEE, E. H., T. F. PALUCHOWSKI and L. R. BEACH. 1992. "The Effects of Screening and Task Partitioning upon Evaluations of Decision Options." Journal of Behavioral Decision Making, Vol. 5, 1-23.

VLEK, C. 1987. "Towards a Dynamic Structural Theory of Decision Behavior." Acta Psychologica, Vol. 66, 225-230. 
RÉSUMÉ

Deux théories à l'appui de la fusion syndicale

La fusion des syndicats s'intensifie à mesure que le salariat lutte pour survivre et prospérer dans un contexte perturbé. Au Canada, par exemple, les syndicats ont été confrontés à de graves récessions, à la concurrence étrangère, au déclin de l'emploi dans les entreprises syndiquées et à la restructuration du secteur public (Chaison 1996). Et il y a peu de chances que le contexte s'améliore dans un proche avenir. Alors, les syndicats canadiens étudient la fusion comme un moyen d'améliorer leur croissance, leur pouvoir et leur propre capacité stratégique (Chaison 1996; Stratton-Devine 1992).

Les dirigeants syndicaux ont mis des alliances en marche (Brooks et Gamm 1976), mais la réalisation de la plupart des fusions dépend en bout de ligne du vote des syndiqués qui est obligatoire en vertu de la constitution des syndicats. Il est assez étonnant que la recherche sur la fusion syndicale soit pratiquement silencieuse sur cet aspect. On s'est peu penché en effet sur le processus de prise de décision relativement à la fusion syndicale, et la documentation ne fait état d'aucune théorie sur ce sujet.

La présente recherche étudie la prise de décision sur la fusion dans le rang des syndiqués. Elle fait appel à deux hypothèses : la théorie de la décision rationnelle (modèle d'optimisation) et la théorie de l'image (modèle comportemental). Les données de l'étude ont été collectées à partir d'une situation où les membres du Syndicat des travailleurs de l'énergie et de la chimie (STEC), le Syndicat canadien des travailleurs du papier (SCTP) et le Syndicat des travailleurs et travailleuses en communication et en électricité du Canada (STCC) ont voté pour appuyer une fusion à trois.

\section{Méthodes et échantillon}

Avant le vote, un outil de sondage, conçu pour mesurer les perceptions du syndiqué sur le principal effet de la fusion (théorie de la décision rationnelle), la compatibilité avec les partenaires de la fusion proposée (théorie de l'image) et le degré d'appui du répondant à la fusion, a été remis aux délégués syndicaux dont le vote était décisif.

L'échantillon était composé des 332 délégués du STEC qui devaient voter sur la fusion. Ce groupe a été choisi en raison de sa connaissance approfondie de la fusion en cause et, plus important encore, parce que ses membres constituaient les votants dont le choix était décisif. En août 1992, durant le congrès biennal du STEC (avant le vote sur la fusion), une lettre explicative, le questionnaire de recherche (en français et en 
anglais) et une envelopperéponse préaffranchie ont fait partie de la pochette de matériel du congrès remis aux délégués. À ce moment, les délégués étaient au courant des négociations en cours sur la fusion et, par conséquent, connaissaient l'alliance proposée. Nous leur demandions de remplir le questionnaire et de le retourner dans l'envelopperéponse. Cent vingt-six délégués l'ont fait, soit un pourcentage de 37,9\%.

\section{Procédés de mesure}

Variables dépendantes. Deux variables dépendantes ont servi à mesurer le degré d'appui accordé à la fusion : une concernant la fusion avec les travailleurs du papier et l'autre la fusion avec les travailleurs en communication et en électricité. Ces deux variables ont été mesurées d'après une échelle de 1 (fort appui) à 5 (forte opposition) en réponse à la question : "Indiquez dans quelle mesure vous appuyez la fusion avec les travailleurs du papier ou avec les travailleurs en communication et en électricité ».

Variables relatives à l'instrumentalité de la fusion. Trois variables composées : croissance, pouvoir et capacité stratégique (StrattonDevine 1992) ont servi à mesurer les effets présumés de l'instrumentalité. Chacun des éléments des variables a été mesuré d'après une échelle de 1 (fort désaccord) à 5 (fort accord).

Variables relatives à l'image. Deux variables agrégées ont servi à mesurer la perception des répondants quant au degré de compatibilité de chacun des deux syndicats avec la propre image de valeur des décideurs : la compatibilité avec les travailleurs du papier (Alpha de Cronbach $=0,91$ ) et la compatibilité avec les travailleurs en communications et en électricité (Alpha de Cronbach $=0,87$ ).

\section{Résultats}

Les résultats de la recherche indiquent que les perceptions autant relativement à l'image qu'à l'instrumentalité déterminent l'appui du syndiqué à la fusion. Le gain de pouvoir et de capacité stratégique a considérablement influé sur l'appui à la fusion avec les travailleurs du papier.

Il est intéressant de remarquer que les membres du STEC n'ont pas perçu de gains importants à réaliser par la fusion avec les travailleurs en communication et en électricité au regard de la croissance, du pouvoir et de la capacité stratégique pris séparément. Cependant le groupement des trois variables donne des résultats significatifs. Il faut donc en conclure que l'instrumentalité devient un facteur important lorsqu'on groupe tous les éléments utilisés pour la mesurer. Lorsque chacun de ces éléments est pris séparément, l'instrumentalité apparaît peu importante. Malgré le fait que les répondants croient que plus de gains seraient réalisés par la 
fusion avec le SCTP, ils accordent un appui plus fort à la fusion avec le STCC $(4,2$ vs 3,$6 ; t=5,6$, p. $<0,001)$. L'examen des moyennes sur les éléments de l'image en fournit l'explication. Les membres du STEC estiment avoir plus de compatibilité avec les travailleurs en communication et en électricité qu'avec les travailleurs du papier (3,9 pour le STCC vs 3,5 pour le SCTP; $t<0,001$ ). Il est donc fort probable qu'ils perçoivent les membres du STCC plus proches d'eux quant à la scolarité et à l'expertise technologique.

Du point de vue théorique, l'étude indique que l'image du partenaire de la fusion proposée aussi bien que l'instrumentalité devraient être prises en considération pour l'examen du comportement du votant.

\section{RESÚMEN}

Soporte para la unificación de los sindicatos, una historia de dos teorías

Este estudio examina las decisiones del sindicato de los trabajadores de la industria de la energía y la química en su elección de ya sea apoyar o estar en contra de la unificación del sindicato con el sindicato de los trabajadores de la industria del papel y el sindicatos de los trabajadores de las comunicaciones y la electricidad. Dos teorías, una económica y la otra relacionada con el comportamiento, fueron utilizadas para explicar las elecciones en el momento de votar de cada trabajador. Los resultados demuestran que consideraciones instrumentales y de imagen necesitan considerarse en el pronostico de los resultados de la votación de esta unificación. 